\title{
A LONGITUDINAL EXAMINATION OF ENVIRONMENTAL REPORTING PRACTICES IN MALAYSIA
}

\author{
Bakhtiar Alrazi \\ Maliah Sulaiman \\ Nik Nazli Nik Ahmad
}

A content analysis of the annual reports of 96 Malaysian companies in 1999, 2003 and 2006 finds that the number of companies reporting on the environment increased from 47 percent in 1999 to 60 percent in 2003, and further increased to 67 percent in 2006. However, the extent of environmental reporting as measured by the number of environmental sentences and disclosure scores (using a self-constructed disclosure index) indicates a low quality of disclosure. Overall, the disclosure is ad-hoc and predisposed towards building a "good corporate citizen" image. The increasing trend, however, is consistent with the prediction of social issue life cycle theory.

Keywords: content analysis; disclosure index; environmental reporting; Malaysia; social issue life cycle theory 
Gadjah Mada International Journal of Business, January -April 2009, Vol. 11, No. 1

\section{Introduction}

Research on environmental reporting in Malaysia has examined the extent of environmental information disclosed in annual reports (ACCA 2002, 2004; Thompson and Zakaria 2004), the motivation for and determinants of environmental reporting (Ahmad et al. 2003; Buniamin and Jaffar 2004; Nik Ahmad and Sulaiman 2004; Yusoff et al. 2006; Smith et al. 2007; Sumiani et al. 2007; Buniamin et al. 2008), and the reliability of such information (Jaffar et al. 2002). However, these studies are predominantly cross-sectional in nature. Thus, their findings tend to be fragmented and incomparable.

Murthy and Abeysekera (2008) argue that an examination of disclosure practices using a longitudinal approach would reveal possible variations in disclosure practices not evident in a cross-sectional study. We therefore undertake a longitudinal study. Longitudinal studies may also reveal the factors which influence changes in reporting practices over time (Nik Ahmad et al. 2003; Ahmad et al. 2003; Thompson and Zakaria 2004). Although there have been several longitudinal studies on environmental reporting trends in Malaysia (ACCA 2002, 2004) these studies are not based on any theoretical framework. The absence of theory is a fundamental weakness and makes it difficult to explain the findings. Consequently, this provides the major motivation for the present study.
There is also a paucity in literature which examines the quality of environmental disclosure. Except for studies by Jaffar et al. (2002) and Smith et al. (2007), other studies focus on the quantity of reporting (Nik Ahmad and Sulaiman 2004; Thompson and Zakaria 2004) or whether the companies are reporting or not (Ahmad et al. 2003; Buniamin et al. 2008). Moreover, ACCA (2002, 2004) and Smith et al. (2007) only provide qualitative description of the environmental reporting. According to Jones and Alabaster (1999), this can be very subjective and they further propose the use of disclosure index which is more precise, accurate and effective.

The study has two objectives. Firstly, this research investigates whether there is a significant change in the number of companies reporting environmental disclosures in the annual reports in 1999, 2003 and 2006. Secondly, this study examines whether the quantity and quality of the environmental information disclosed have significantly changed in the same period.

Our study is significant for three reasons. This study contributes to the dearth in the literature pertaining to developing and newly-industrializing economies. Since this study is longitudinal, trends in reporting practices may be observed. Additionally, this study uses the social issue life cycle theory to explain its findings. Secondly, this study examines both the quantity and the quality of environmental disclosures. Thirdly, the results will provide evidence of the level of readiness 
amongst Malaysian companies to implement environmental reporting. Subsequently, any attempt to develop environmental reporting standards should consider the current level of reporting practices.

The paper is organized as follows. The second section, describes the development pertaining to environmental legislation and reporting standards in Malaysia. The third section, reviews the literature. The fourth section, discusses the theoretical framework and the development of hypotheses. The fith section, reports research method. The sixth section, provides the findings, and the final section, concludes.

\section{Development of Environmental Legislation and Reporting Guidelines in Malaysia}

There are numerous signs of increased environmental awareness in Malaysia in recent years. First, environmental legislation is now more stringent, and stiffer penalties have been imposed for non-compliance. The Environmental Quality Act of 1974(EQA 1974) (Act 127) was amended in 1998 and further in 2001 to include the prohibition of open burning (EQA 1974). The amendments also saw substantial increases in penalties for various environmental offences. Additionally, between 1999 and 2003 only, there were 10 subsidiary legislations introduced (EQA 1974). These developments attest to the increasing governmental concern about environmental impacts of business operations in Malaysia.

Secondly, there are several authoritative guidelines that explicitly make reference to environmental reporting. These include the publications of FRS 101 and FRS 137 (formerly known as MASB 1 and MASB 20) by the Malaysian Accounting Standards Board(MASB) in 1999 and 2001, respectively, the Malaysian Code on Corporate Governance (MCCG) in 2000, and the ACCA's Environmental Reporting Guidelines in 2003 and later the Sustainability Reporting Guidelines in 2005. ${ }^{1}$ In the latest development, Bursa Malaysia (Malaysian Stock Exchange) has come up with its CSR Framework whereby effective year 2007, all public listed companies in Malaysia are required based on Paragraph 29, Appendix 9C, of the Listing Requirementsto report their socialcontributions (including environmental issues) in the annual reports. However, the framework only provides a basic guideline to the companies regarding what areas of social activities

\footnotetext{
${ }^{1}$ For instance, paragraph 10 of FRS 101- Presentation of Financial Statements, states that business entities may "present outside the financial statements, additional statements such as environmental reports...” Meanwhile, FRS 137 -Provisions, Contingent Liabilities and Contingent Assets issued in 2001, provides examples of environmental contingent liabilities. Besides, MCCG (2000) recommends the board of directors to assess the environmental performance of their companies, as stipulated in paragraph XVII of the Part 2.
} 
Gadjah Mada International Journal of Business, January -April 2009, Vol. 11, No. 1

and/or performance that they need to inform the public.

Another development is the introduction of two environmental reporting awards, the National Annual Corporate Report Awards (NACRA) that includes a category of environmental reporting in 2000, and the Malaysian Environmental Reporting Awards (MERA) by ACCA in 2002 [This was replaced by the Malaysian Social and Environmental Reporting Awards (MESRA) in 2004 and later, the Malaysian Sustainability Reporting Awards (MaSRA) in 2009].

Finally, environmental awareness campaigns have been launched by the DOE as well as non-governmental organizations (NGOs) such as Sahabat Alam Malaysia (SAM), Malaysian Nature Society (MNS), Business Council for Sustainable Development Malaysia (BCSDM) and Environmental Protection Society of Malaysia (EPSM). This constitutes anecdotal evidence of the increased public and governmental concerns over the environment which may lead to enhanced environmental reporting practices by Malaysian companies.

\section{Review of The Literature}

Prior studies on corporate environmental reporting practices suggest that while there appears to be an increasing trend in the number of companies reporting environmental information, the overall level of reporting is still low (Niskala and Pretes 1995; KPMG 1999, 2002; Moneva and Llena
2000). Among corporate social disclosure themes, environmental (and energy) disclosure ranks third behind human resources and product or community information in both the number of reporting companies and the amount of reported information (Gray et al. 1995a; Hackston and Milne 1996; Tsang 1998; Abu-Baker and Naser 2000; Imam 2000).

Second, environmental disclosures have been predominantly narrative in nature. Very few companies disclose quantitative environmental information (Niskala and Pretes 1995; Moneva and Llena 2000; ACCA 2002).

Third, the evidence also suggests that companies are more predisposed towards disclosing good news information. Fourth, there is limited evidence of companies which engage in external verification of environmental reports (Niskala and Pretes 1995; KPMG 1999).

Finally, there appears to be no specific preferred location in the annual report for environmental reporting. Perhaps, most companies tend to disclose information in voluntary sections of the annual reports since these sections are normally not audited (Walden and Schwartz 1997).

Whilst there is limited literature on environmental reporting in Malaysia, the evidence appears consistent with that of studies conducted in other countries. Results reveal that environmental disclosures are mainly declarative and self-laudatory in nature (Jaffar et al. 2002; Ahmad et al. 2003; Nik 
Ahmad and Sulaiman 2004; Sumiani et al. 2007). Additionally, there is also evidence that firms' environmental disclosures increase with firm size, environmental performance (Jaffar et al. 2002), leverage, audit firm (Ahmad et al. 2003) and the ISO 14001 certification (Sumiani et al. 2007). Findings of Smith et al. (2007), on the other hand, suggest that poor financial performance is associated with increased environmental disclosure.

Finally, in the absence of any regulatory requirements, companies tend to focus on the enhancement of their "corporate image" (ACCA 2004; Buniamin and Jaffar 2004), although there is also limited evidence of other motives such as the companies' selfenvironmental concerns and operational improvements (Yusoff et al. 2006).

However, most of these studies are cross-sectional. Even though the ACCA $(2002,2004)$ conducted a longitudinal study covering the period between 1999 and 2003, it lacks a theoretical underpinning which is necessary to explain the reporting practices. This study contributes to the literature using social issue life cycle theory as the framework to put the reporting trends in context. Besides, many prior content analysis studies on environmental reporting have used different checklist instruments to examine environmental disclosure. This may lead to different or inconsistent results which would prevent any meaningful comparison. Accordingly, this study utilizes checklist instruments that are well established in the environmental reporting literature. This will not only ensure consistency, but more importantly, it will allow for comparisons with those of similar studies in other countries.

Another contribution of this study is the examination of both the quantity and the quality of environmental disclosure. Except for Jaffar et al. (2002) and Smith et al. (2007), there has been no published work on the quality of disclosure in Malaysia. Jaffar et al. (2002) however merely look at the location and the degree of quantification (i.e., monetary, non-monetary, and general) of the environmental information. Meanwhile, Smith et al.(2007) do not provide any clear description on how they come up with the disclosure items. Besides, it is crucial that studies on environmental disclosure examine both quantity and quality of disclosure as findings from such studies will provide valuable insights for regulatory bodies in setting guidelines or standards to environmental reporting.

\section{Theoretical Framework and Hypotheses Development}

Social issues are described by Mahon and Waddock (1992: 20) as "problems that may exist objectively but become issues that require managerial attention when they are defined as being problematic to society or an institution within society by a group of actors or stakeholders capable of influencing either governmental actions or company policies.” Meanwhile, 
Gadjah Mada International Journal of Business, January -April 2009, Vol. 11, No. 1

Zyglidopoulos (2003: 71) defines issues as "a controversial inconsistency based on one or more expectational gaps of what is considered appropriate behavior within a particular society... with implications for corporate performance and behavior.”

Issue evolution may be examined from either macro or micro perspective (Zyglidopoulos 2003). From a macro perspective, changes in societal expectation may indicate that an issue has evolved. One of the prominent models is the public policy perspective, whereby an issue becomes politicized before it is made a regulation (Post 1978, as cited in Mahon and
Waddock 1992). The development in the environmental regulations and reporting recommendations as described earlier is an example of the evolution of issue from the macro perspective.

On the other hand, a micro perspective of issue evolution looks at the behavior of companies. Thus, changes in the environmental reporting practices of companies over time may signal 'environment' as an issue that requires managerial attention. Regardless of the perspective -macro or micro, most social issue theorists agree that an issue progresses from a period of insignificance to a period of increased public attention. Subsequently,

Table 1. Stages in Social Issue Life Cycle

Phases

Phase 1: Policy

Phase 2: Learning

Phase 3: Commitment

\section{Characteristics}

- A given social or environmental issue first emerges as a top management concern

- There is no systematic analysis of problem, and the policy statements are followed by little or no organisational action

- Addition to the corporate staff of a specialist (or specialists) who is given the responsibility of implementing the company's social policy

- The specialist's job is initially very poorly defined, with no clear definition of his or her authority or responsibilities

- Organisational responsiveness is integrated into ongoing business decisions and becomes the responsibility of line managers

- Supplementary reporting and auditing practices aimed at social issues are often implemented, and performance evaluation criteria begin to include social issues 
the public will demand necessary actions from business organizations involved. The actions then gradually become the norms for the organizations in dealing with such issues (Nasi et al. 1997; Zyglidopoulos 2003). This becomes the premise of social issue life cycle theory.

Social issue life cycle-theory posits that an issue evolves through three to four predictable stages (Mahon and Waddock 1992; Bigelow et al. 1993; Nasi et al. 1997; Zyglidopoulos 2003). However, an issue may not necessarily evolve according to the "normal" path (i.e., stage by stage) since issue evolution may be affected by factors such as sudden intervention of government or other influential stakeholders or the emergence of other issues that require immediate attention and shift attention away from the existing issue (Bigelow et al. 1993; Nasi et al. 1997). Table 1, suggested by Ackerman(1975) cited from Nasi et al. (1997), summarizes the stages in the social issue life cycle.

Several studies have utilized social issue life cycle theory to explain the corporate social responsibility initiatives and reporting. Nasi et al.(1997) examined the annual reports of two major Canadian and Finnish forestry companies over a 16-year period, i.e., 1976-1991. They find that social issues played a moderate role in the annual report disclosures of all four companies between 1976 and early 1980s. There was a significant reduction in the attention paid to societal issues in the mid-1980s. Then, coin- ciding with the general heightened awareness on environmental issues in the late 1980s, there was an increased emphasis on societal issues in the annual reports. This trend of increased disclosure on a range of social issues provides some evidence of the applicability of social issue life cycle theory.

Eweje (2005, 2006a, 2006b) examined inter alia the motives for corporate social responsibility initiatives undertaken by companies from the multinational mining and oil industries operating in Nigeria and South Africa. These companies receive mounting pressure from the community due to significant impacts their operations have on the natural environment and the perception that they have not provided enough social and economic infrastructure/assistance to the community. The author finds the applicability of social issue life cycle theory in several instances. Firstly, the fatalities rate and injuries rate in the mining industry dropped from 1984 to 1998 by 23.2 percent and 38.05 percent, respectively (Eweje 2005).

Secondly, although in the early phase it seemed that only Shell (one of the oil companies) demonstrated its commitment towards environmental preservation (since 1958), by 1997, all other oil companies began to promote green initiatives and include environmental issues in their strategic planning process (Eweje 2006a).

Thirdly, both oil and mining companies appear also to become more proactive over time by establishing community relations departments to 
Gadjah Mada International Journal of Business, January -April 2009, Vol. 11, No. 1

engage their stakeholders, and their commitments towards the environment are explicitly described in the mission statements, statements of business principles and the Chairman's statements (Eweje 2006b).

Meanwhile, previous research finds that a firm's voluntary environmental disclosure increases with environmental incidents or prosecutions (Patten 1992; Deegan and Rankin 1996; Walden and Schwartz 1997; Neu et al. 1998), substantial media exposure (Brown and Deegan 1998; Neu et al. 1998; Cormier and Magnan 2003), and the prominent role of the environmental lobbying groups (Deegan and Gordon 1996; Campbell 2004). Other studies suggest that heightened environmental awareness, as in the Malaysian context described earlier, could also lead to changes in environmental reporting trends over time (Niskala and Pretes 1995; Moneva and Llena 2000).

Thus, if companies in Malaysia perceive the increasing public awareness on environmental issues as a potential threat, social issue life cycle theory asserts that there will be a change in the environmental reporting practices of these companies. Previous studies on Malaysia find that the number of reporting companies and the quantity of environmental disclosure increase over time (ACCA 2002, 2004; Haniffa and Cooke 2005). Although these studies do not look at quality, studies in other countries document evidence of the increase in the quality of the reported information (Walden and
Schwartz 1997; Buhr and Freedman 2001; Hooks et al. 2004). Therefore, it is reasonable to develop hypotheses in a directional form. These hypotheses, stated in the alternate, are as follows: $H_{A} 1$ : There is a significant increase in the number of companies disclosing environmental information in 1999, 2003 and 2006.

$H_{A}$ 2: There is a significant increase in the quantity of environmental information disclosed in 1999, 2003 and 2006.

$H_{A} 3$ : There is a significant increase in the quality of environmental information in 1999, 2003 and 2006.

\section{Sample Selection and Research Methods}

\section{Sample Selection}

This study is an extension of Alrazi (2005), who examined the environmental reporting practices between 1999 and 2003. He used the largest 150 companies (by market capitalization) listed on the Main Board as of 31 December 2003 as the sample for his study due to the following reasons. Firstly, literature finds a significant association between size and corporate disclosure (Neu et al. 1998; Williams 1999; Jaffar et al. 2002; Cormier and Magnan 2003, Ramasamy and Hung 2004).

Secondly, larger companies are more visible and, thus, are perceived to have greater impact on society 
(Hackston and Milne 1996). Moreover, there is a possibility that these companies have more socially and environmentally conscious shareholders (Hackston and Milne 1996). Additionally, these companies are believed to have more resources to embark on social and environmental initiatives (Cormier and Magnan 2003; Ramasamy and Hung 2004).

Forty companies were excluded due to new listing status (18 companies), corporate restructuring (19), ceased operations (2) and unavailability of annual reports (1). These reduced his final sample to only 110 companies. We further investigate whether these companies were still listed on Bursa Malaysia in year 2006.
We find that only 96 companies were still listed (seven companies were delisted and the remaining underwent other corporate restructurings) and this makes up our sample. We choose year 2006 due to two main reasons. Firstly, effective year 2007, all public listed companies are required to adopt the Bursa Malaysia CSR Framework, which requires the companies to disclose their environmental performance information (see Second section).

Secondly, this is the most recent data available when the research commenced. Table 2 provides a description of the sample.

Table 2 shows that four sectors: mining, closed end funds, hotels and trusts are not represented. Neverthe-

Table 2. Distribution of Companies According to Industrial Sector

\begin{tabular}{|c|c|c|c|c|}
\hline No & Industry & Sample & Population* & $\%$ \\
\hline 1 & Closed end funds & 0 & 1 & 0 \\
\hline 2 & Construction & 6 & 41 & 15 \\
\hline 3 & Consumer products & 12 & 73 & 16 \\
\hline 4 & Finance & 16 & 52 & 31 \\
\hline 5 & Hotels & 0 & 5 & 0 \\
\hline 6 & Industrial products & 12 & 123 & 10 \\
\hline 7 & Infrastructure project companies & 4 & 8 & 50 \\
\hline 8 & Mining & 0 & 2 & 0 \\
\hline 9 & Plantation & 8 & 39 & 21 \\
\hline 10 & Properties & 8 & 88 & 9 \\
\hline 11 & Technology & 3 & 15 & 20 \\
\hline 12 & Trading/Services & 27 & 116 & 23 \\
\hline 13 & Trusts & 0 & 3 & 0 \\
\hline \multicolumn{2}{|c|}{ Total } & 96 & 566 & 17 \\
\hline
\end{tabular}

*The population is as of 31 December 2003. 
Gadjah Mada International Journal of Business, January -April 2009, Vol. 11, No. 1

less, this will not significantly affect the results since these sectors are among the least likely sectors to report environmental information (KPMG 1999, 2002; ACCA 2002, 2004; Ahmad et al. 2003) whereas for mining, there are only two companies in the industry.

\section{Content Analysis - Measurement of Dependent Variables}

Content analysis is a "research technique for making replicable and valid inferences from data to their context” (Krippendorf 1980: 21). Content analysis involves specialized procedures for processing scientific data (Krippendorf 1980; Weber 1990). The emphasis is on the definition, medium, measurement and construction of the categorization scheme (Gray et al. 1995b; Milne and Adler 1999).

Definition. For this study, environmental reporting refers to disclosure of the impact a company's activities have on physical or natural environment(Wilmshurst and Frost 2000). The checklist proposed by Hackston and Milne (1996), Williams (1999) and Deegan et al. (2002) are used in this study. Minor modifications are made. The final checklist provides an improved representation of environmental issues that a company may disclose in its annual report (Appendix A).

Medium. This study only utilizes annual reports as the source of information due to several reasons. Using annual reports would be consistent with previous studies (Hackston and Milne 1996; Nik Ahmad and Sulaiman 2004; De Villiers and Van Staden 2006).

Secondly, annual reports are a primary information source of environmental performance for investors, creditors, employees, environmental groups and the government (Wiseman 1982; Tilt 1994).

Thirdly, compared to other media, annual reports possess a high degree of credibility (Tilt 1994; Gray et al. 1995b; Neu et al. 1998; Unerman 2000).

Fourthly, annual reports are more accessible to researchers (Gray et al. 1995b; Unerman 2000; Wilmshurst and Frost 2000), and it would not be possible to identify all corporate communications on social matters over a long period of time (Gray et al. 1995b; Campbell 2004).

Finally, the limited use of standalone environmental reports justifies the use of annual reports in this study (ACCA 2002; Thompson and Zakaria 2004).

\section{Data Measurement and Capture}

Level. The level of reporting is measured based on the existence of environmental information in the annual reports. The information may be reported in any form including words, sentences, graphics, captions, graphics, etc. Companies that report some form of environmental information is coded " 1 " (reporting), otherwise " 0 " (non-reporting). 
Alrazi, Sulaiman, \& Nik Ahmad-A longitudinal Examination of Environmental Reporting Practices in Malaysia

Table 3. Categorisation Scheme for Environmental Information

\begin{tabular}{|c|c|c|}
\hline No. & Dimensions & Sub-categories \\
\hline 1 & Evidence & Monetary, non-monetary, declarative \\
\hline 2 & News type & Good news, bad news, neutral \\
\hline 3 & Location & $\begin{array}{l}\text { Financial statements, environmental section, } \\
\text { Chairman's Statement, operations review, corporate } \\
\text { diary/highlight, others }\end{array}$ \\
\hline
\end{tabular}

Quantity. The quantity of disclosure signifies the importance of an issue (Krippendorf 1980). Previous studies have used words, sentences, proportion of a page, line count and frequency. Consistent with Alrazi (2005), this study uses the number of sentences to measure quantity for several reasons. Firstly, sentences can be used to depict meaning and thus are likely to provide more reliable measures (Hackston and Milne 1996). The use of sentences also reduces the degree of subjectivity in interpreting the environmental information disclosed (Milne and Adler 1999).

Secondly, Hackston and Milne (1996) find high correlations amongst sentences, words and pages. Hence, the results should not be greatly influenced by the choice of sentences, instead of words, or proportion of a page.

The next step is to develop a categorization scheme classifying each item into several dimensions (Milne and Adler 1999). Previous studies use evidence, amount, location, news type, environment sub-themes and mandatory/voluntary characteristic (Milne and Adler 1999). This study, however, adapts the classification scheme used in Nik Ahmad and Sulaiman (2004) and Alrazi (2005). For the "location" dimension, financial statements (including the director's report and notes to the accounts) and the environmental section are added as sub-categories. Meanwhile, the "environmental subthemes" dimension is removed (see Table 3).

Quality of Disclosure. Alrazi (2005) develops a disclosure index to assess the quality of information. The index measures the comprehensiveness of environmental information in terms of its breadth and depth. Accordingly, this reflects the comprehensiveness of disclosed items, and thus their quality. In addition, measuring quantity in sentences excludes information in the form of photos, graphs, and charts. The quality measure, through the disclosure index, overcomes the limitation of the quantity measure. This definition of quality was also used by authors like Davis-Walling and Batterman (1997), Elkington et al. (1998), Morhardt (2001) and Morhardt et al. (2002).

There are two stages in developing a disclosure index (Owusu-Ansah 
1998). The first involves determining the items to be included. The items included are derived from studies by Wiseman (1982), Walden and Schwartz (1997), Davis-Walling and Batterman (1997), Elkington et al. (1998), Morhardt (2001), Morhardt et al. (2002) and Krut and Munis (1998). Additionally, the disclosure index includes the adjudication criteria used in MERA (currently, MaSRA) and NACRA. Other items are derived from the GRI's guidelines (Global Reporting Initiative) as well as the ACCA environmental reporting guidelines (ACCA 2003).

As a result, the index has 100 items grouped into 14 categories: corporate context, corporate commitment, environmental policy, targets and achievements, environmental management systems, environmental impacts, performance data, research and development, third party statements, compliance/non-compliance, financial data, stakeholders' engagement and other environmental initiatives, awards, and report designs (see Appendix B).

The second stage involves quantifying the items in the index to determine the extent to which a company has disclosed environmental issues. This takes into account several important considerations. Firstly, a dichotomous system awards one point for a company that discloses the item and zero for non-disclosure (i.e., $1=$ disclosed; $0=$ non-disclosed). Secondly, a polychotomous system awards points based on an ascending scale. For ex- ample, a zero for non-disclosure, a " 1 ” for minimal, a " 2 " for satisfactory disclosure and a " 3 " for comprehensive disclosure.

Alrazi (2005) score the environmental reporting on an unweighted and dichotomous basis. The main reason for using a dichotomous basis is to avoid unnecessary bias (Banks et al. 1997; Owusu-Ansah 1998). Nevertheless, the disclosure scores for each company are based on the ratio of what the reporting company discloses to what it is expected to disclose. This ratio is referred to as the relative index (Owusu-Ansah 1998). The relative index is calculated to ensure that the company will not be penalised for nondisclosure of information that is not relevant to it.

Meanwhile, Cooke (1989) supports the unweighted scoring system since the overall effect of subjective evaluation by various groups of respondents is minimal. He also finds that firms better at disclosing important items are also better at disclosing less important items. Finally, previous empirical findings suggest that the results from unweighted and weighted scoring systems are not statistically different (Chow and Boren 1987; Robbins and Austin 1986; Coy et al. 1993; Wallace, Kamal and Mora 1994; Coy and Dixon 2004).

\section{Reliability of the Findings}

Krippendorf (1980) emphasises the importance of the reliability of the content analysis. We undertake two stages of reliability tests. First, the first 
author conducts a content analysis of the 2002 annual reports of 20 companies from various industries. This is consistent with Milne and Adler (1999)'s argument that at least 20 annual reports are needed in a pilot study before the findings can be considered reliable.

We conducted a stability test using the test-retest procedure during the actual data collection (Krippendorf 1980). The annual reports are reexam- ined, one month after the first attempt. No significant differences in the results are evident.

\section{Findings and Analysis}

\section{Number of Reporting Companies}

Table 4 provides the distribution of reporting companies by industry. It can be observed that in 1999, only

Table 4. Distribution of Disclosing Companies According to Industrial Classification

\begin{tabular}{|c|c|c|c|c|c|c|c|c|}
\hline \multirow[t]{2}{*}{ No } & \multirow[t]{2}{*}{ Industry } & \multirow{2}{*}{$\begin{array}{c}\text { Sample } \\
\text { Companies }\end{array}$} & \multicolumn{2}{|c|}{$\begin{array}{l}\text { Disclosure } \\
\text { in } 1999\end{array}$} & \multicolumn{2}{|c|}{$\begin{array}{l}\text { Disclosure } \\
\text { in } 2003\end{array}$} & \multicolumn{2}{|c|}{$\begin{array}{c}\text { Disclosure } \\
\text { in } 2006\end{array}$} \\
\hline & & & Total & $\%$ & Total & $\%$ & Total & $\%$ \\
\hline 1 & Construction & 6 & 3 & $50 \#$ & 5 & 83 & 5 & 83 \\
\hline 2 & Consumer products & 12 & 8 & 67 & 8 & 67 & 8 & 67 \\
\hline 3 & Finance & 16 & 3 & 19 & 5 & 31 & 7 & 44 \\
\hline 4 & Industrial products & 12 & 7 & 58 & 11 & 92 & 10 & 83 \\
\hline 5 & IPC & 4 & 3 & 75 & 1 & 25 & 2 & 50 \\
\hline 6 & Plantation & 8 & 5 & 63 & 8 & 100 & 8 & 100 \\
\hline 7 & Properties & 8 & 3 & 38 & 5 & 63 & 4 & 50 \\
\hline 8 & Technology & 3 & 0 & 0 & 2 & 67 & 3 & 100 \\
\hline \multirow[t]{6}{*}{9} & Trading/services & 27 & 13 & 48 & 13 & 48 & 17 & 63 \\
\hline & Total & 96 & 45 & 47 & 58 & 60 & 64 & 67 \\
\hline & & & & 1999 & \multirow{3}{*}{\multicolumn{3}{|c|}{$\begin{array}{l}\text { McNemar test } \\
(\text { Chi-square value })^{+}\end{array}$}} & $3.892 *$ \\
\hline & & & & 2003 & & & & \\
\hline & & & & 1999 & & & & $8.308 * *$ \\
\hline & & & 1999, & $2003 \&$ & \multicolumn{3}{|c|}{$\begin{array}{l}\text { Cochran test } \\
\text { (Cochran's Q value) }\end{array}$} & $1.792 * *$ \\
\hline
\end{tabular}

* Significant at 0.05 level (two-tailed); ** Significant at 0.01 level (two-tailed)

\# $\quad(3 / 6) * 100 \%$

+ The change in the reporting companies between 2003 and 2006 is minor. McNemar test uses binomial distribution and as such no corresponding Chi-square value is provided. 
companies in the Technology sector did not include environmental information in their annual reports. However, starting in 2003, all sectors have at least one company disclosing such information in annual reports. Also, there was a significant increase in the number of reporting companies from $45(47 \%)$ in 1999 to 64 (67\%) in 2006 $(\mathrm{p}=0.01) .{ }^{2}$ While a significant increase is observed from 1999 to 2003, a similar pattern is not evident in the disclosure practice between 2003 and 2006. We also find that 34 companies have consistently reported some form of environmental information every year, whereas 25 companies do not report in any year.

\section{Quantity of Reporting}

The quantity of environmental reporting is based on the number of sentences (see Appendix C for descriptive statistics). Table 5 provides the environmental disclosure categories in terms of evidence, news type and location. The average number of sentences disclosed in 1999 was 3.83, and this increased to 14.10 sentences in $2003(\mathrm{p}=0.000)$ but later dropped to 12.27 sentences in 2006. ${ }^{3}$ However, the drop is insignificant. Overall, the information is merely declarative. Further, eventhough there was a significant increase in the number of companies providing monetary environmental information in 2003, almost 50 percent of them related to sponsorship activities.

Consistent with previous research (Deegan and Gordon 1996; Nik Ahmad and Sulaiman 2004), most companies tend to neglect bad news disclosure. When it is disclosed, it often focuses on contingent liabilities. Some companies do disclose environmental accidents but such disclosures lack clarity. Furthermore, the information is normally accompanied by sentences indicating that the problem is not very severe.

In one case, no details are provided regarding measures undertaken to ensure such incidents will not recur. Meanwhile, in the case of another company, although it describes preventive measures in the subsequent sentence, no quantitative information is provided

\footnotetext{
${ }^{2}$ We perform McNemar test to see any difference in the number of reporting companies between 1999-2003, 2003-2006 and 1999-2006. This is consistent with Niskala and Pretes (1995). Similarly, we also test any difference between 1999, 2003 and 2006 using Cochran test. We do not use Friedman $\chi^{2}$ test as in Moneva and Llena (2000) since the test is not suitable for categorical data used in this case where reporting is denoted as " 1 " and " 0 " otherwise.

${ }^{3}$ We run Kolmogrov Smirnov Z-test to test the data normality, where significance level of less than 5 percent indicates that the distribution of the data is not normal (de Vaus 2002). Since the data are not normally distributed, we run non-parametric tests of Wilcoxon signed rank test to see any difference in the reporting between 1999-2003, 2003-2006 and 1999-2006; and Friedman $\chi^{2}$ test for the difference between 1999, 2003 and 2006. This is consistent with Walden and Schwartz (1997) and Moneva and Llena (2000). The equivalent parametric tests are also conducted (as suggested by Choi 1999) and we find that the results are consistent with non-parametric tests.
} 
Alrazi, Sulaiman, \& Nik Ahmad-A longitudinal Examination of Environmental Reporting Practices in Malaysia

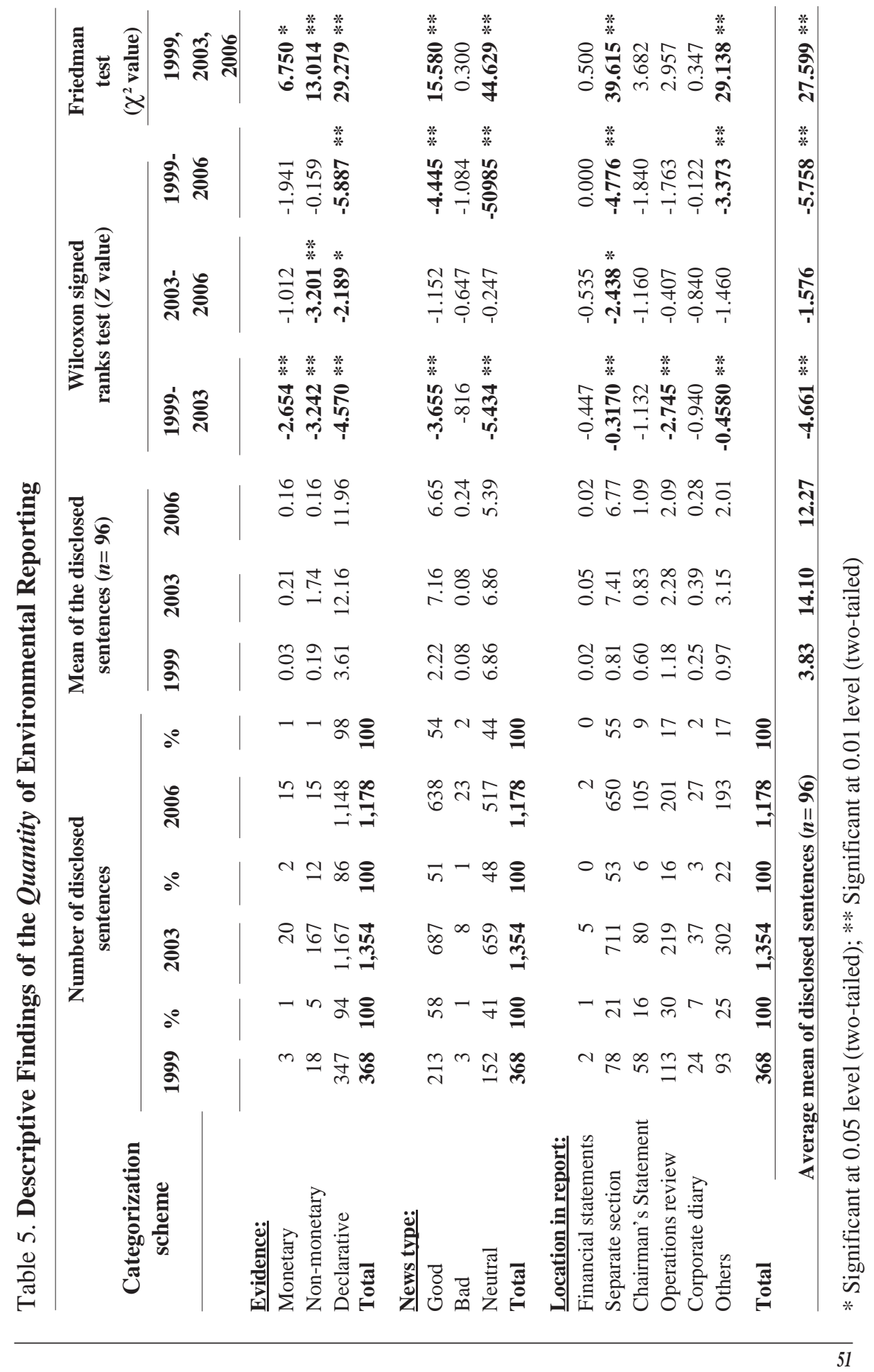


in terms of the externalities produced. Also, there is no disclosure on the possible impacts on the surrounding habitat.

For 1999, most of the disclosure was located in the Operations Review section (30\% of total number of sentences). However, in 2003 and 2006, the most preferred location was a separate section on the environment. Such disclosure accounted for 51 percent and 55 percent of the total number of sentences respectively. This suggests that companies are increasingly putting greater importance on environmental disclosure. Disclosure of environmental information in the financial statements is almost non-existent. This is perhaps due the fact that financial statements are under the purview of the auditors.

\section{Quality of Reporting}

Table 6 provides the results of the trend in environmental reporting quality (see Appendix C for descriptive statistics). One point is given for each item disclosed in each category, and the disclosure score (DS) is computed by adding all the points in that category. The total possible scores for each disclosure category are also reported to provide a more accurate picture of the quality of information.

Overall, there was a significant increase in the quality of reported information $(\mathrm{p}=0.000)$, between 1999 and 2003, and 1999 and 2006, but not between 2003 and 2006. In 1999, the mean of DS was 4.11, in 2003 was 7.47, and in 2006 was 6.82. This ap- pears to indicate that, on average, Malaysian companies only manage to meet 4 percent to 7 percent of the criteria included in the disclosure index. Thus, even though there is an increase, the quality is still very low. Additionally, it can be observed that most of the disclosures emphasize "environmental policy" (i.e., 30\% of disclosure scores in each year). This might be due to the highest number of items allocated under this category. Additionally, unlike information on targets, performance, compliance and financial which are quantitative and objective in nature, policy is rather subjective and subject to less scrutiny by the public, relevant authorities and other interested parties.

None of the companies has an independent verification of the information disclosed. This reduces the credibility of the environmental information disclosed. Furthermore, most companies do not disclose environmental achievements against predetermined targets. Additionally, it appears that companies in Malaysia have made no effort to adopt any reporting guidelines.

Overall, the number of reporting companies significantly increases from 45 to 64 companies. At the same time, increases in the quantity and quality of environmental reporting are also significant. These indicate that companies respond to the increased environmental awareness by disclosing more environmental information. However, the absence of significant increases in the overall quantity and quality of the 
Alrazi, Sulaiman, \& Nik Ahmad-A longitudinal Examination of Environmental Reporting Practices in Malaysia

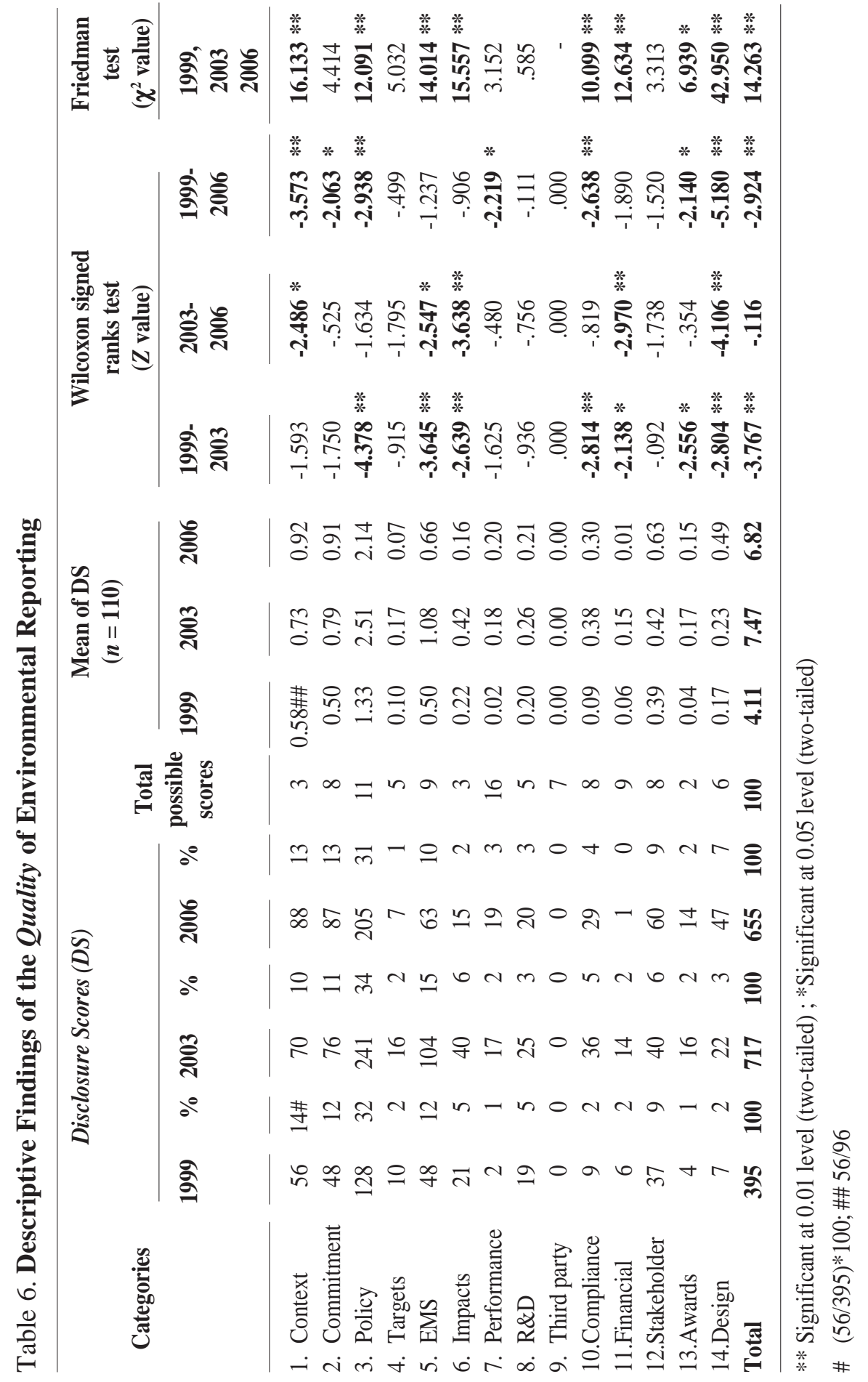


reported information between 2003 and 2006 suggest that the hypotheses cannot be supported.

A closer look at individual companies' quantity and quality of reporting reveal that the significant increase in 2003 and the reduction in 2006 could be attributed to the following instances (refer Appendix D). Golden Hope Plantations Berhad and Kumpulan Guthrie Berhad experienced an increase by 5.42 times $(0.30$ times) and 1.64 times (0.60 times), respectively, in the quantity (quality) of reporting in 2003. On the contrary, in 2006, they showed a decrease by 0.77 times ( 0.41 times) and 0.61 times (0.44 times) in the quantity (quality). This could be due to the proposed merger between these two companies and another company, Permodalan Nasional Berhad, to form Synergy Drive Berhad in 2006 such that reporting on the environment might be perceived as less important than informing the shareholders on the implications of the impending merger.

Coincidently, United Plantations Berhad shows a decrease by 62 percent and 25 percent in the quantity and quality of reporting, respectively. Since both Golden Hope and Guthrie are plantation companies, a reduction in the reporting of these companies may have an impact on the reporting of United Plantations as the company may face less pressure to report on the environment to the public. The decrease in the reporting of Shell Refining Company (FOM) Berhad and Puncak Niaga Holdings Berhad is rather surprising. Perhaps, the requirements on environmental reporting by Bursa Malaysia indicate that reporting more information may trigger unwanted attention from regulators (Graham et al.2005). Despite this, there are other companies that continuously improve their reporting practices, including Nestle (M) Berhad, Telekom Malaysia Berhad, Petronas Gas Berhad and IJM Corporation Berhad.

Nasi et al. (1997) do not find a pattern of steady increase in the corporate social reporting of Finnish and Canadian forestry companies, suggesting that although the life cycle effect holds over the long term, it is moderated by other influences. Similarly, in this study, we find that reporting significantly increased from 1999 to 2006. However, there was a decrease in the quantity and quality of reporting in 2006 due to several possible reasons presented above. Thus, the findings provide limited supports to the prediction of social issue life cycle theory.

\section{Conclusion}

This study examines whether there are any significant changes in the environmental reporting practices of 96 companies in Malaysia. Results show that there was a significant increase in the number of reporting companies, from 45 in 1999 to 64 in 2006. Meanwhile, quantity, measured by the number of sentences, increased by 2.20 times in 2006. DS, which measures the quality of environmental information, significantly increased from 4.11 in 
1999 to 6.82 in 2006. All these findings provide limited supports for social issue life cycle theory.

This study contributes to the body of knowledge, particularly with the discussion of social issue life cycle theory in the context of environmental reporting practices in Malaysia. Additionally, it provides evidence of the level of readiness amongst Malaysian companies prior to the possible implementation of mandatory reporting.

The results of this study should be interpreted with care. Firstly, environmental disclosure is only measured in the annual reports of 1999, 2003 and 2006. Therefore, it does not capture any change in the years between them. As such, it fails to conclude whether environmental information has been reported every year. Future studies may consider including the annual reports for these years. Furthermore, a study on an extended period, say 10 to 15 years, may enrich our understanding of environmental reporting practices.

Secondly, it focuses on the content analysis of the annual reports, thereby raising some concerns. The first concern relates to the issue of subjectivity. However, the problem is minimized by using an established checklist instrument and decision rules for the definition of environmental reporting and undertaking a two-stage coding/scoring process. The second concern is that it ignores other media such as environmental reports, newspapers, brochures and company web sites. Future research may examine environmental reporting in other company publications. The third concern relates to the assumption that the annual reports represent the ultimate perception of the company on environmental issues. Thus, a low level of disclosure indicates a low level of importance attached by the companies towards environmental issues. This might not be necessarily true (Jaggi and Zhao 1996; Nik Ahmad and Abdul Rahim 2005). Therefore, questionnaire surveys or interviews may be used to supplement findings from a content analysis study.

Thirdly, this study focuses only on the top 96 companies (by market capitalization). As such, it may not be able to generalize the findings to small companies. Since it does not consider small companies that may have reported environmental information, the quality of their environmental information - based on the disclosure index- is relatively unknown. In addition, our study examines large companies that have continuously been listed between 1999 and 2006. Accordingly, there may exist a survivor bias.

Fourthly, the disclosure index utilized for the present study examines completeness as a proxy for quality of disclosure. We do acknowledge that the quality of disclosure is not confined to only completeness. Instead, in addition to comprehensiveness, it may also encompass adequacy, informativeness, and timeliness of the information (Wallace et al. 1994). Perhaps 
future studies may modify the disclosure index to also capture these other dimensions of quality.

Finally, the study does not examine any corporate characteristics of companies disclosing environmental information. There are several variables that may explain environmental reporting behavior. These include environmental sensitivity, size of company, profitability, financial leverage, and foreign ownership. Future research in the area may examine the relationships amongst these variables and the quantity and quality of environmental reporting.

\section{References}

Abu-Baker, N., and K. Naser. 2000. Empirical evidence on corporate social disclosure (CSD) practices in Jordan. International Journal of Commerce and Management 10 (3 and 4): 18-34.

Ackerman, R. W. 1975. The Social Challenge to Business. Cambridge, MA: Harvard University Press.

Ahmad, Z., Hassan, S., and J. Mohammad. 2003. Determinants of environmental reporting in Malaysia. International Journal of Business Studies 11 (1): 69-90.

Alrazi, B. 2005. Comparing environmental reporting practices of public-listed companies in Malaysia in 1999 and 2003: An investigation of quantity and quality. Unpublished Masters’ Thesis. Malaysia: International Islamic University Malaysia.

Banks, W., J. Fisher, and M. Nelson. 1997. University accountability in England, Wales, and Northern Ireland: 1992-1994. Journal of International Accounting, Auditing and Taxation 6 (2): 211-226.

Bigelow, B., L. Fahey, and J. F. Mahon. 1993. A typology of issue evolution. Business and Society 32 (1): 18-29.

Brown, N., and C. Deegan. 1998. The public disclosure of environmental performance information - A dual test of media agency setting theory and legitimacy theory. Accounting and Business Research 29 (1): 21-41.

Buhr, N., and M. Freedman. 2001. Culture, institutional factors and differences in environmental disclosure between Canada and the United States. Critical Perspectives on Accounting 12: 293 - 322.

Buniamin, S., B. Alrazi, N. H. Johari, and N. R. Abd Rahman. 2008. An investigation of the association between corporate governance and environmental reporting in Malaysia. Asian Journal of Business and Accounting 1 (2): 65 - 88.

Buniamin, S., and R. Jaffar. 2004. Environmental reporting in Malaysia: Perspective of the management. Management Accounting Review 3 (1): 43-59.

Bursa Malaysia. 2004. Bursa Malaysia Listed Companies Announcements. http:// www.bursamalaysia.com/website/bm/listed companies/company announcements/ annual reports/index.jsp (accessed November 1). 
Alrazi, Sulaiman, \& Nik Ahmad-A longitudinal Examination of Environmental Reporting Practices in Malaysia

Bursa Malaysia. 2009. Listing Requirements of Bursa Malaysia Securities Berhad.

Campbell, D. 2004. A longitudinal and cross-sectional analysis of environmental disclosure in UK companies - a research note. The British Accounting Review 36: 107-117.

Choi, J. S. 1999. An investigation of the initial voluntary environmental disclosures made in Korean semi-annual financial reports. Pacific Accounting Review 11 (1): 73-102.

Chow, C. W., and A. W. Boren. 1987. Voluntary financial disclosure by Mexican corporations. The Accounting Review 62 (3): 533-541.

Cooke, T. E. 1989. Disclosure in the corporate annual reports of Swedish companies. Accounting and Business Research 19 (74): 113-124.

Cormier, D., and M. Magnan. 2003. Environmental reporting management: A continental European perspective. Journal of Accounting and Public Policy 22: 43-62.

Coy, D., and K. Dixon. 2004. The public accountability index: Crafting a parametric disclosure index for annual reports. The British Accounting Review 36: 79-106.

Coy, D., G. Tower, and K. Dixon. 1993. Quantifying the quality of tertiary education annual reports. Accounting and Finance 33: 121-129.

Davis-Walling, P. and S. A. Batterman. 1997. Environmental reporting by the Fortune 500 firms. Environmental Management 21 (6): 865-875.

De Vaus, D. 2002. Analyzing Social Science Data (1 ${ }^{\text {st }}$ ed.). London: SAGE Publications Ltd.

De Villiers, C., and C. J. Van Staden. 2006. Can less environmental disclosures have a legitimizing effect? Evidence from Africa. Accounting, Organizations and Society 31: 763-781.

Deegan, C., and B. Gordon. 1996. A study of the environmental disclosure practices of Australian corporations. Accounting and Business Research 26 (3): 187-199.

Deegan, C., and M. Rankin. 1996. Do Australian companies report environmental news objectively? An analysis of environmental disclosures by firms prosecuted successfully by the environmental protection authority. Accounting, Auditing and Accountability Journal 2: 50-67.

Deegan, C., M. Rankin, and J. Tobin. 2002. An examination of the corporate social and environmental disclosures of BHP from 1983-1997 - a test of legitimacy theory. Accounting, Auditing and Accountability Journal 15 (3): 312-343.

Elkington, J., N. Kreander, and H. Stibbard. 1998. The third international survey on company environmental reporting: The 1997 benchmark survey. Greener Management International 21: 99-112.

Environmental Quality Act. 1974. Act 127.

Eweje, G. 2005. Hazardous employment and regulatory regimes in the South African mining industry: Arguments for corporate ethics at workplace. Journal of Business Ethics 56: 163 - 183.

Eweje, G. 2006a. Environmental costs and responsibilities resulting from oil exploitation in developing countries: the case of the Niger Delta of Nigeria. Journal of Business Ethics 69: 27 - 56. 
Gadjah Mada International Journal of Business, January -April 2009, Vol. 11, No. 1

Eweje, G. 2006b. The role of MNEs in community development initiatives in developing countries - Corporate social responsibility at work in Nigeria and South Africa. Business and Society 45 (2): $93-129$.

Finance Committee on Corporate Governance. 2000. Malaysian Code on Corporate Governance. Kuala Lumpur.

Global Reporting Initiative. 2002. Sustainability Reporting Guidelines. Boston.

Graham, J. R., C. R. Harvey, and S. Rajgopal. 2005. The economic implications of corporate financial reporting. Journal of Accounting and Economics 40: 3-73.

Gray, R., R. Kouhy, and S. Lavers. 1995a. Corporate social and environmental reporting - a review of the literature and a longitudinal study of UK disclosure. Accounting, Auditing and Accountability Journal 8 (2): 47-77.

Gray, R., R. Kouhy, and S. Lavers. 1995b. Methodological themes - constructing a research database of social and environmental reporting by UK companies. Accounting, Auditing and Accountability Journal 8 (2): 78-101.

Hackston, D., and M. J. Milne. 1996. Some determinants of social and environmental disclosures in New Zealand companies. Accounting, Auditing and Accountability Journal 9 (1): 77 - 108.

Haniffa, R. M., and T. E. Cooke. 2005. The impact of culture and governance on corporate social reporting. Journal of Accounting and Public Policy 24: 391 - 430.

Hooks, J., K. Kearins, and M. Blake. 2004. Effective environmental disclosure? An evaluation of power generators' reporting initiatives. New Zealand Applied Business Research 2 (2): 40 - 58.

Imam, S. 2000. Corporate social performance reporting in Bangladesh. Managerial Auditing Journal 15 (3): 133-141.

Jaffar, R., T. Mohd. Iskandar, and I. Muhamad. 2002. Investigation of environmental disclosures: Evidence from selected industries in Malaysia. International Journal of Business and Society 3: 55-68.

Jaggi, B., and R. Zhao. 1996. Environmental performance and reporting: Perceptions of managers and accounting professionals in Hong Kong. The International Journal of Accounting 31 (3): 333 - 346.

Jones, K., and T. Alabaster. 1999. Critical analysis of corporate environmental reporting scoring system. Journal of Environmental Assessment Policy and Management 1(1): 27-60.

KPMG. 1999. KPMG International Survey of Environmental Reporting 1999. Amsterdam: KPMG Environmental Consulting.

KPMG. 2002. KPMG International Survey of Corporate Sustainability Reporting 2002. Amsterdam: KPMG Global Sustainability Services.

Krippendorf, K. 1980. Content Analysis - An Introduction to its Methodology. California: Sage Publications Inc.

Krut, R., and K. Munis. 1998. Sustainable industrial development: Benchmarking environmental policies and reports. Greener Management International 21: 87-98. 
Alrazi, Sulaiman, \& Nik Ahmad-A longitudinal Examination of Environmental Reporting Practices in Malaysia

Mahon, J. F., and S. A. Waddock. 1992. Strategic issues management: An integration of issue life cycle perspectives. Business and Society 31 (1): 19-32.

Malaysian Accounting Standards Board. 1999. MASB 1 - Presentation of Financial Statements. Kuala Lumpur.

Malaysian Accounting Standards Board. 2001. MASB 20 - Provisions, Contingent Liabilities and Contingent Assets. Kuala Lumpur.

Milne, M. J., and R. W. Adler. 1999. Exploring the reliability of social and environmental disclosures content analysis. Accounting, Auditing and Accountability Journal 12 (2): 237-256.

Moneva, J. M., and F. Llena. 2000. Environmental disclosures in the annual reports of large companies in Spain. The European Accounting Review 9 (1): 7 - 29.

Morhardt, J. E. 2001. Scoring corporate environmental reports for comprehensiveness: A comparison of three systems. Environmental Management 27 (6): 881-892.

Morhardt, J. E., S. Baird, and K. Freeman. 2002. Scoring corporate environmental and sustainability reports using GRI 2000, ISO 14031 and other criteria. Corporate Social Responsibility and Environmental Management 9: 215-233.

Murthy, V., and I. Abeysekera. 2008. Corporate Social Reporting Practices. The Australasian Accounting Business and Finance Journal 2 (1) (February): 36 - 59.

Nasi, J., S. Nasi, N. Phillips, and S. C. Zyglidopoulos. 1997. The evolution of corporate social responsiveness - an exploratory study of Finnish and Canadian forestry companies. Business and Society 36 (3): 296-321.

Neu, D., H. Warsame, and K. Pedwell. 1998. Managing public impressions: environmental disclosures in annual reports. Accounting, Organisations and Society 23 (3): 265282.

Nik Ahmad, N. N., and M. Sulaiman. 2004. Environmental disclosures in Malaysian annual reports: A legitimacy theory perspective. International Journal of Commerce and Management 14 (1): 44-58.

Nik Ahmad, N. N., and N. L. A. Abdul Rahim. 2005. Awareness of corporate social responsibility among selected companies in Malaysia - an exploratory note. Malaysian Accounting Review 4 (1): 11-24.

Nik Ahmad, N. N., M. Sulaiman, and D. Siswantoro. 2003. Corporate social responsibility disclosure in Malaysia: An analysis of annual reports of KLSE listed companies. IIUM Journal of Economics and Management 11 (1): 51-86.

Niskala, M., and M. Pretes. 1995. Environmental reporting in Finland: A note on the use of annual reports. Accounting, Organisations and Society 20 (6): 457-466.

Owusu-Ansah, S. 1998. The impact of corporate attributes on the extent of mandatory disclosure and reporting by listed companies in Zimbabwe. The International Journal of Accounting 33 (5): 605-631.

Patten, D. M. 1992. Intra-industry environmental disclosures in response to the Alaskan oil spill: A note on legitimacy theory. Accounting, Organisations and Society 17 (5): 471-475. 
Gadjah Mada International Journal of Business, January -April 2009, Vol. 11, No. 1

Post, J. E. 1978. Corporate Behavior and Social Change. Virginia: Reston Publishing Co.

Ramasamy, B., and W. T. Hung. 2004. A comparative analysis of corporate social responsibility awareness - Malaysian and Singaporean firms. Journal of Corporate Citizenship 13: 109-123.

Robbins, W. A., and K. R. Austin. 1986. Disclosure quality in governmental financial reports: An assessment of the appropriateness of a compound measure. Journal of Accounting Research 24 (2): 412-421.

Smith, M, K. Yahya, and A. M. Amiruddin. 2007. Environmental disclosure and performance reporting in Malaysia. Asian Review of Accounting 15 (2): 185-199.

Sumiani, Y., Y. Haslinda, and G. Lehman. 2007. Environmental reporting in a developing country: a case study on status and implementation in Malaysia. Journal of Cleaner Production 15: 895 - 901.

The Association of Chartered Certified Accountants. 2002. The State of Corporate Environmental Reporting in Malaysia. London: Certified Accountants Educational Trust.

The Association of Chartered Certified Accountants. 2003. Environmental Reporting Guidelines for Malaysian Companies. London: Certified Accountants Educational Trust.

The Association of Chartered Certified Accountants. 2004. Malaysian Environmental ReportingAwards.http://www.accaglobal.com/sustainability/awards/mera/(accessed October 31)

The Association of Chartered Certified Accountants. 2004. Report Summary - The State of Corporate Environmental and Social Reporting in Malaysia 2004. London: Certified Accountants Educational Trust.

The Association of Chartered Certified Accountants. 2005. Sustainability Reporting Guidelines for Malaysian Companies. London: Certified Accountants Educational Trust.

Thompson, P., and Z. Zakaria. 2004. Corporate social responsibility reporting in Malaysia - progress and prospects. Journal of Corporate Citizenship 13: 125-136.

Tilt, C. A. 1994. The influence of external pressure groups on corporate social disclosure: Some empirical evidence. Accounting, Auditing and Accountability Journal 7 (4): 56-71.

Tsang, E. W. K. 1998. A longitudinal study of corporate social reporting in Singapore the case of the banking, food and beverages and hotel Industries. Accounting, Auditing and Accountability Journal 11 (5): 624 - 635.

Unerman, J. 2000. Methodological issues: Reflections on quantification in corporate social reporting content analysis. Accounting, Auditing and Accountability Journal 13 (5): 667-680.

Walden, W. D. and Schwartz, B. N. 1997. Environmental disclosures and public policy pressure. Journal of Accounting and Public Policy 16: 125-154. 
Alrazi, Sulaiman, \& Nik Ahmad-A longitudinal Examination of Environmental Reporting Practices in Malaysia

Wallace, R. S., N. Kamal, and A. Mora. 1994. The relationship between the comprehensiveness of corporate annual reports and firm characteristics in Spain. Accounting and Business Research 25 (97): 41-53.

Weber, R. P. 1990. Basic Content Analysis ( $2^{\text {nd }}$ ed.). California: Sage Publications Inc.

Williams, S. M. 1999. Voluntary environmental and social accounting disclosure practices in the Asia-Pacific region: An international empirical test of political economy theory. The International Journal of Accounting 34 (2): 209-238.

Wilmshurst, T. D., and G. F. Frost. 2000. Corporate environmental reporting: A test of legitimacy theory. Accounting, Auditing and Accountability Journal 13 (1): 10-26.

Wiseman, J. 1982. An evaluation of environmental disclosures made in corporate annual reports. Accounting, Organisations and Society 7 (1): 53-63.

Yusoff, H., G. Lehman, and N. Mohd. Nasir. 2006. Environmental engagements through the lens of disclosure practices - a Malaysian story. Asian Review of Accounting 14 (1/2): $122-148$.

Zyglidopoulos, S. C. 2003. The issue life cycle: Implications for reputation for social performance and organisational legitimacy. Corporate Reputation Review 6 (1): 70 81. 
Gadjah Mada International Journal of Business, January -April 2009, Vol. 11, No. 1

\section{Appendix A}

\section{Checklist instrument}

(Note: The italic words/sentences are amendments made after the pilot study)

\begin{tabular}{|c|c|c|}
\hline No & Areas & Items \\
\hline 1 & $\begin{array}{l}\text { General environmental } \\
\text { considerations } \\
\text { (environmental } \\
\text { pollution) }\end{array}$ & $\begin{array}{l}\text { - Statement of the corporation’s business operations on environmental pollution } \\
\text { pertaining to noise, air, water and visual quality } \\
\text { - Statements indicating that the company's operations are non-polluting or that } \\
\text { they are in compliance with pollution laws and regulations }{ }^{\S} \\
\text { - Recognition of the need to comply with society standards and regulations }{ }^{ø} \S \\
\text { Statement of the capital, operating, and research and development expendi- } \\
\text { tures and activities of the environmental pollution produced by the firm with } \\
\text { respect to noise, air, water and visual quality }\end{array}$ \\
\hline 2 & Environmental policy & $\begin{array}{l}\text { - Actual statement of policy } \\
\text { - Statement of formal intentions } \\
\text { - Statements indicating that company will undertake certain measures to curb } \\
\text { environmental pollution and other such damage or what the company does }\end{array}$ \\
\hline 3 & Environmental audit & $\begin{array}{l}\text { - Reference to environmental review, scoping, audit, assessment including } \\
\text { independentattestation }\end{array}$ \\
\hline 4 & $\begin{array}{l}\text { Environmental } \\
\text {-product and } \\
\text { process related }\end{array}$ & 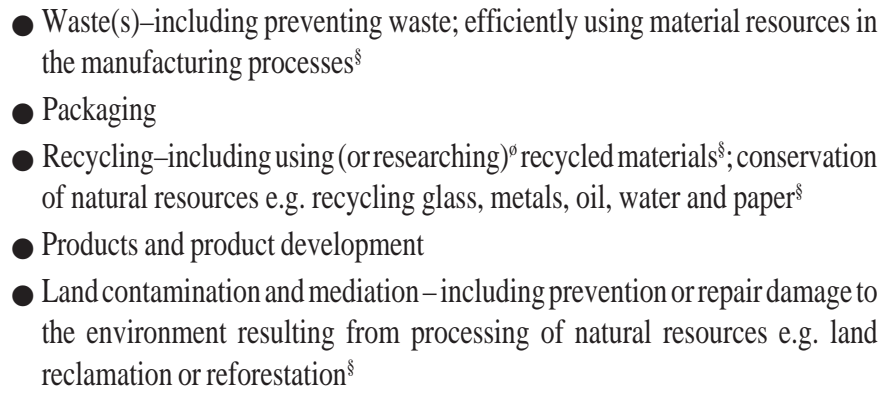 \\
\hline 5 & $\begin{array}{l}\text { Environmental } \\
\text { financially related data }\end{array}$ & $\begin{array}{l}\text { - Reference to financial//economic impact } \\
\text { - Investment and investment appraisal } \\
\text { - Discussion of areas with financial/economic impact } \\
\text { - Discussion of environmental-economic interaction }\end{array}$ \\
\hline 6 & Sustainability & $\begin{array}{l}\text { - Any mention of sustainability } \\
\text { - Any mention of sustainable development }\end{array}$ \\
\hline 7 & $\begin{array}{l}\text { Environmental } \\
\text { Aesthetics }\end{array}$ & $\begin{array}{l}\text { - Designing facilities harmonious with the environment } \\
\text { - Contributions in terms of cash or plants/flowers to beautify the environment } \\
\text { - Natural landscaping }\end{array}$ \\
\hline
\end{tabular}


Alrazi, Sulaiman, \& Nik Ahmad-A longitudinal Examination of Environmental Reporting Practices in Malaysia

\section{Continued from Appendix A}

Areas
Environmental - Other

Sources: Williams (1999), Hackston and Milne (1996) $)^{\S}$ and Deegan et al. (2002)

\section{Decision rules}

1. All sponsorship activity is to be included no matter how much it is advertising

2. All disclosures must be specifically stated, they cannot be implied

3. Good/neutral/bad classifications to be determined from the perspective of the stakeholder group involved

- Good: statements beyond the minimum which include (for example) specific details where these details have a creditable or neutral reflection on the company; any statements which reflect credit on the company; upbeat analysis/discussion/statements;

- Bad: any statement which reflects/might reflect discredit on the company;

- Neutral: statement of policy or intent within statutory minimum with no details of what or how; statement of facts whose credit/discredit to the company is not obvious - which are unaccompanied by editorialising (Gray et al., 1995b: 99).

4. Tables (monetary or non-monetary) which provide information which is on the checklist should beinterpreted as one line equals sentence. However, if the tables provide information in a narrative sentence, the treatment is similar to the other sentences in the normal text 
Gadjah Mada International Journal of Business, January -April 2009, Vol. 11, No. 1

\section{Continued from Appendix A}

- Qualitative (declarative) information includes all verbal disclosure.

- Quantitative (non-monetary) information refers to environmental measures such as emission levels and forest materials consumed in production by volume.

- Financial information (monetary) includes all environmental information expressed in monetary terms (Niskala and Pretes 1995:457).

5. Any captions to graphical information will be considered as environmental information if they help in understanding the information provided in the text. In another way, it should be related to the text.

6. Any disclosure which is represented shall be recorded as an environmental sentence each time it is discussed. Nevertheless, if the information is provided in another language i.e. Malay and/or Chinese, only those in English will be considered.

7. All classifications are undertaken with care so as to ensure that the disclosure is not part of the business (e.g. waste disposal, environmental technology or oil exploration companies)

8. Such information will be excluded (Nik Ahmad and Sulaiman 2004):

a. References to industrial concerns about environmental issues

b. Statements on changing public perceptions

9. The phrase "health, safety and environment" may be considered as environmental information as long as it does not obviously relate to health and safety issues of the working environment which might otherwise be considered as social information. 


\section{Appendix B}

\section{Disclosure Index}

\begin{tabular}{llll}
\hline No & Categories & Points $\begin{array}{c}\text { Total } \\
\text { points (\%) }\end{array}$ \\
\hline
\end{tabular}

1 Corporate context

- Description of products and/or services

- Identification of the boundary of the report

口 Environmental information is provided for each major business operation

口 Environmental performance of other related parties is included

\section{Corporate commitment}

\section{- Vision and missiono}

口 The vision statement of the organization mentions anything on environment

口 The mission statement of the organisation mentions anything on environment

\section{- Chairman/CEO Statemento}

口 Environmental information is included in the statement 1

口 Mentions, in brief, the organisation's environmental policy 1

口 Highlights the commitment by the organisation's leadership to environmental issues and objectives

口 Highlights the achievement in the current period-include both success and failure

口 Identifies issues and challenges facing the organisation

口 Future environmental strategy

\section{Environmental policy}

- There is an environmental policy or an indication that any publicly established charters is being subscribed by the company 1

- There is a set of environmental goals and objectives

- The environmental goals and objectives should, at a minimum, state a commitment to:

口 Materials, water and energy conservation

口 Waste, emissions and discharges managemen

口 Continuous process improvement and monitoring

1

口 Supply chain management and/or product stewardship 1

ฉ Biodiversity maintenance and preservation 1

口 Compliance with environmental laws and regulations 1

口 Stakeholder relation management 1

口 Environmental performance reporting 1

口 Recognition of the improved performance 1 
Gadjah Mada International Journal of Business, January -April 2009, Vol. 11, No. 1

\section{Continued from Appendix B}

\section{No}

$$
\text { Categories }
$$

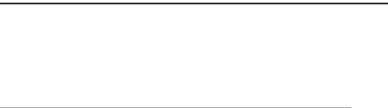

Points

Total

points (\%)

4 Targets and achievement

- There are specific environmental targets to be achieved

- The target should cover all key environmental issues facing the organization

- Achievement (or progress) against targets are indicated

- Reasons for any non-achievement of those targets

- Associated remedial or preventive actions

5 Environmental management systems

- The organization has an environmental management system, or planning (and status) of implementation

- There are members of the board/division/department responsible for environmental management

- The board/division/department is responsible for the whole environmental issues in the organization

- Identification of the key managerial responsibilities for the various aspects of the system which includes:

口 Contingency planning and risk management

口 Internal audit and review

口 Environmental impact assessment

- The environmental management system is externally certified or planned (and expected date) to be certified

- Clear identification on the process/facilities involved in the certification

- Training programs and related educational activities for staff

6 Environmental impacts

- Identification of significant environmental impacts of the organization's activities, products and services

- The implication should the impacts are not mitigated

- The hiring of environmental specialists or external auditors to facilitate the identification of environmental impacts

7 Performance data

- Energy-absolute (joules); normalized; trends over time; comparative data within sector

- Materials-absolute (tones, volume or kilograms); normalized; trends over time; comparative data within sectors

- Water-absolute (liters or cubic meters); normalized; trends over time; comparative data within sectors

- Emissions, effluents and waste-absolute (tones or kilograms); normalized; trends over time; comparative data within sectors
1

1

1

1

1

5 


\section{Continued from Appendix B}

\begin{tabular}{|c|c|c|c|}
\hline No & Categories & Points & $\begin{array}{c}\text { Total } \\
\text { points }(\%)\end{array}$ \\
\hline 8 & $\begin{array}{l}\text { Research and development } \\
\text { - There are research and development initiatives undertaken } \\
\text { on environmental improvements } \\
\text { - Environmental objectives for the improvements are clearly set out } \\
\text { - Actual and forecasted capital expenditures, liabilities } \\
\text { - Financial qualification benefits } \\
\text { - Collaborate on research and development with non-industrial } \\
\text { stakeholders }\end{array}$ & $\begin{array}{l}1 \\
1 \\
1 \\
1\end{array}$ & 5 \\
\hline 9 & $\begin{array}{l}\text { Third party statement } \\
\text { - There is a statement by an external party to verify the information } \\
\text { - The statement clearly states: } \\
\text { 口 Remit and scope } \\
\square \text { Indication of site visits and site-specific testing } \\
\square \text { Interpretation of data/performance reported } \\
\square \text { Indication of any data/information omitted that could/should have been } \\
\text { included } \\
\square \text { Independent comment on corporate targets set and impacts identified }\end{array}$ & $\begin{array}{l}1 \\
1 \\
1\end{array}$ & \\
\hline & 口 Shortcomings and recommendation & 1 & 7 \\
\hline
\end{tabular}

\section{Compliance/non-compliance}

- The recognition of any pollution or environmental laws and regulations which the organization's operations are subject to

- Statement indicates whether the organization is in compliance with such laws and regulations

- List the number of sites or departments that have received complaints or have been prosecuted

- Total number of fines paid or volume of fines/complaints

- Any environmental accidents that resulted in any significant environmental impact

- Procedures that have been put in place to prevent such incidents

- Comparison of the data over time

- Comparison of the data within sector

11 Financial data

- There is an environmental financial statement

- The environmental information is integrated within conventional financial statement

- The company practices full environmental cost accounting 
Gadjah Mada International Journal of Business, January -April 2009, Vol. 11, No. 1

\section{Continued from Appendix B}

\begin{tabular}{|c|c|c|c|}
\hline No & Categories & Points & $\begin{array}{c}\text { Total } \\
\text { points (\%) }\end{array}$ \\
\hline & 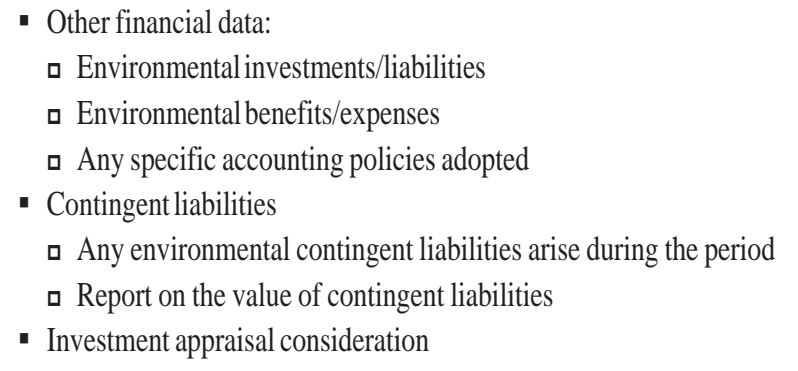 & $\begin{array}{l}1 \\
1 \\
1\end{array}$ & 9 \\
\hline 12 & $\begin{array}{l}\text { Stakeholder engagement and other environmental initiatives } \\
\text { - Stakeholder engagement } \\
\text { 口 Indication of stakeholder engagement in practice } \\
\text { 口 Approaches to stakeholder consultation } \\
\text { 口 Type of information generated } \\
\text { 口 Use of the feedbacks } \\
\text { - Community outreach program } \\
\text { 口 Indication that an organization has conducted a community } \\
\text { outreach program } \\
\text { - Details such as date, place and participation } \\
\text { - Supporting any environmental campaigns/environmental initiatives } \\
\text { by external parties } \\
\text { - Charitable contributions to or partnership with environmental } \\
\text { organizations }\end{array}$ & $\begin{array}{l}1 \\
1 \\
1 \\
1\end{array}$ & 8 \\
\hline
\end{tabular}

\section{Awards}

- Any reporting awards received by an organization

- Others

\section{Report design}

- Indication of any relevant reporting guidelines followed 1

- Innovative approaches

- Appropriate graphics

- Communication and feedback mechanism

口 Name of the person or department responsible with preparing the reports 1

口 Telephone number or email address

- Separate environmental section is devoted in the annual report

Note: The criteria used under "Performance data" is as follows: absolute (1 mark), normalized (1), trends over time (1) and comparative data within sector (1), to make up a total of 4 marks for each item under this category 
Alrazi, Sulaiman, \& Nik Ahmad-A longitudinal Examination of Environmental Reporting Practices in Malaysia

\section{Appendix C}

Descriptive statistics for interval variables

\begin{tabular}{|c|c|c|c|c|c|c|}
\hline & $\begin{array}{c}\text { Sentences } \\
1999\end{array}$ & $\begin{array}{c}\text { Sentences } \\
2003\end{array}$ & $\begin{array}{c}\text { Sentences } \\
2006\end{array}$ & $\begin{array}{c}\text { DS } \\
1999\end{array}$ & $\begin{array}{c}\text { DS } \\
2003\end{array}$ & $\begin{array}{c}\text { DS } \\
2006\end{array}$ \\
\hline Mean & 3.83 & 14.10 & 12.27 & 4.11 & 7.47 & 6.82 \\
\hline Median & .00 & 1.00 & 4.00 & .00 & 3.00 & 4.50 \\
\hline Std. deviation & 10.199 & 39.551 & 19.385 & 6.416 & 10.251 & 7.631 \\
\hline Minimum & 0 & 0 & 0 & 0.00 & 0.00 & 0.00 \\
\hline Maximum & 61 & 321 & 84 & 30.00 & 44.38 & 36.00 \\
\hline Skewness & 4.012 & 5.658 & 2.080 & 2.134 & 1.812 & 1.661 \\
\hline Std. Error of Skewness & .246 & .246 & .246 & .246 & .246 & .246 \\
\hline Kurtosis & 16.881 & 39.246 & 3.628 & 4.740 & 2.978 & 3.220 \\
\hline Std. Error of Kurtosis & .488 & .488 & .488 & .488 & .488 & .488 \\
\hline Kolmogrov Smirnov Z test (p-value)* & .000 & .000 & .000 & .000 & .000 & .003 \\
\hline
\end{tabular}

*Each individual item under the categorisation scheme (quantity) and disclosure category (quality) were also tested for normality and all of them have a significance value of less than 5 percent which indicates that the data are not normally distributed. 
Gadjah Mada International Journal of Business, January -April 2009, Vol. 11, No. 1

\section{Appendix D}

Distribution of the Quantity and Quality of Environmental Reporting

\begin{tabular}{|c|c|c|c|c|c|c|c|}
\hline \multirow[b]{2}{*}{ No } & \multirow[b]{2}{*}{ Companies } & \multicolumn{3}{|c|}{ Quantity } & \multicolumn{3}{|c|}{ Quality } \\
\hline & & 99 & 03 & 06 & 99 & 03 & 06 \\
\hline 1. & Malayan Banking Bhd & 0 & 10 & 10 & 0 & 8 & 9 \\
\hline 2. & Tenaga Nasional Bhd & 23 & 45 & 37 & 27 & 30 & 18 \\
\hline 3. & Telekom Malaysia Bhd & 0 & 5 & 23 & 0 & 7 & 15 \\
\hline 4. & Public Bank Bhd & 1 & 25 & 21 & 6 & 15 & 16 \\
\hline 5. & Petronas Gas Bhd & 7 & 16 & 70 & 7 & 20 & 29 \\
\hline 6. & Sime Darby Bhd & 0 & 3 & 11 & 0 & 4 & 7 \\
\hline 7. & Genting Bhd & 1 & 14 & 7 & 3 & 16 & 3 \\
\hline 8. & Resorts World Bhd & 6 & 0 & 2 & 8 & 0 & 3 \\
\hline 9. & Commerce-Asset Holding Bhd & 0 & 0 & 3 & 0 & 0 & 6 \\
\hline 10. & IOI Corporation Bhd & 6 & 25 & 50 & 15 & 9 & 10 \\
\hline 11. & Hong Leong Bank & 1 & 0 & 1 & 6 & 0 & 3 \\
\hline 12. & YTL Power International Bhd & 0 & 0 & 11 & 0 & 0 & 4 \\
\hline 13. & YTL Corporation Bhd & 4 & 2 & 58 & 1 & 7 & 16 \\
\hline 14. & Malaysian Airline System Bhd & 1 & 0 & 1 & 6 & 0 & 3 \\
\hline 15. & AMMB Holdings Bhd & 1 & 2 & 8 & 8 & 7 & 11 \\
\hline 16. & Nestle (M) Bhd & 0 & 44 & 70 & 0 & 29 & 35 \\
\hline 17. & Kuala Lumpur Kepong Bhd & 0 & 3 & 21 & 0 & 4 & 10 \\
\hline 18. & Malakoff Bhd & 0 & 5 & 3 & 0 & 9 & 6 \\
\hline 19. & Perusahaan Otomobil Nasional Bhd & 4 & 7 & 18 & 13 & 8 & 12 \\
\hline 20. & Gamuda Bhd & 4 & 2 & 12 & 7 & 4 & 10 \\
\hline 21. & Magnum Corporation Bhd & 0 & 0 & 0 & 0 & 0 & 1 \\
\hline 22. & Tanjong Public Ltd Co & 1 & 5 & 5 & 6 & 11 & 9 \\
\hline 23. & RHB Capital Bhd & 0 & 0 & 0 & 0 & 0 & 1 \\
\hline 24. & Golden Hope Plantations Bhd & 50 & 321 & 71 & 30 & 39 & 23 \\
\hline 25. & Berjaya Sports Toto Bhd & 0 & 0 & 0 & 0 & 0 & 1 \\
\hline 26. & Malaysian Pacific Industries Bhd & 0 & 1 & 4 & 0 & 9 & 4 \\
\hline 27. & Petronas Dagangan Bhd & 5 & 7 & 7 & 9 & 7 & 6 \\
\hline 28. & UMW Holdings Bhd & 19 & 21 & 17 & 18 & 17 & 16 \\
\hline 29. & DiGi.Com Bhd & 2 & 0 & 0 & 6 & 0 & 1 \\
\hline 30. & Kumpulan Guthrie Bhd & 45 & 119 & 46 & 20 & 32 & 18 \\
\hline 31. & Oriental Holdings Bhd & 1 & 0 & 0 & 3 & 0 & 0 \\
\hline 32. & IOI Properties Bhd & 0 & 1 & 0 & 0 & 2 & 0 \\
\hline 33. & DRB-HICOM Bhd & 1 & 14 & 16 & 5 & 12 & 9 \\
\hline 34. & Star Publications (M) Bhd & 3 & 1 & 1 & 5 & 3 & 2 \\
\hline 35. & SP Setia Bhd & 2 & 11 & 13 & 5 & 6 & 9 \\
\hline
\end{tabular}




\section{Continued from Appendix D}

\begin{tabular}{|c|c|c|c|c|c|c|c|}
\hline \multirow[b]{2}{*}{ No } & \multirow[b]{2}{*}{ Companies } & \multicolumn{3}{|c|}{ Quantity } & \multicolumn{3}{|c|}{ Quality } \\
\hline & & 99 & 03 & 06 & 99 & 03 & 06 \\
\hline 36. & Highlands \& Lowlands Bhd & 16 & 58 & 9 & 13 & 24 & 8 \\
\hline 37. & Edaran Otomobil Nasional Bhd & 0 & 4 & 2 & 0 & 5 & 3 \\
\hline 38. & Malaysia Airports Holdings Bhd & 0 & 16 & 35 & 0 & 18 & 13 \\
\hline 39. & Road Builder (M) Holdings Bhd & 0 & 19 & 8 & 0 & 12 & 8 \\
\hline 40. & Sime UEP Properties Bhd & 5 & 27 & 16 & 10 & 13 & 5 \\
\hline 41. & IJM Corporation Bhd & 0 & 48 & 52 & 0 & 17 & 18 \\
\hline 42. & Batu Kawan Bhd & 0 & 1 & 1 & 0 & 3 & 1 \\
\hline 43. & Malaysian Plantations Bhd & 0 & 0 & 0 & 0 & 0 & 1 \\
\hline 44. & Carlsberg Brewery (M) Bhd & 1 & 0 & 7 & 4 & 0 & 6 \\
\hline 45. & Hap Seng Consolidated Bhd & 1 & 0 & 0 & 3 & 0 & 0 \\
\hline 46. & Malaysian Oxygen Bhd & 1 & 2 & 9 & 2 & 2 & 7 \\
\hline 47. & Unisem (M) Bhd & 0 & 1 & 16 & 0 & 3 & 11 \\
\hline 48. & IGB Corporation Bhd & 0 & 0 & 4 & 0 & 0 & 2 \\
\hline 49. & Puncak Niaga Holdings Bhd & 61 & 112 & 67 & 24 & 42 & 17 \\
\hline 50. & PPB Oil Palms Bhd & 0 & 9 & 6 & 0 & 12 & 5 \\
\hline 51. & Islands \& Peninsular Bhd & 9 & 4 & 6 & 10 & 7 & 8 \\
\hline 52. & Lingkaran Trans Kota Holdings Bhd & 1 & 0 & 0 & 5 & 0 & 1 \\
\hline 53. & Fraser \& Neave Holdings Bhd & 4 & 10 & 4 & 6 & 11 & 7 \\
\hline 54. & Shell Refining Co (F.O.M.) Bhd & 15 & 119 & 84 & 11 & 44 & 36 \\
\hline 55. & Hong Leong Industries Bhd & 1 & 1 & 6 & 5 & 8 & 7 \\
\hline 56. & Ramatex Bhd & 0 & 7 & 0 & 0 & 10 & 0 \\
\hline 57. & Asiatic Developments Bhd & 5 & 13 & 17 & 7 & 10 & 10 \\
\hline 58. & Guinness Anchor Bhd & 4 & 2 & 0 & 10 & 5 & 1 \\
\hline 59. & TA Enterprise Bhd & 0 & 0 & 0 & 0 & 0 & 1 \\
\hline 60. & Sarawak Enterprise Corporation Bhd & 0 & 0 & 1 & 0 & 0 & 2 \\
\hline 61. & JT International Bhd & 0 & 0 & 0 & 0 & 0 & 1 \\
\hline 52. & Amway (M) Holdings Bhd & 0 & 1 & 0 & 0 & 3 & 0 \\
\hline 53. & Multi-Purpose Holdings Bhd & 0 & 0 & 0 & 0 & 0 & 1 \\
\hline 54. & Affin Holdings Bhd & 0 & 0 & 0 & 0 & 0 & 0 \\
\hline 55. & Bandar Raya Developments Bhd & 0 & 6 & 0 & 0 & 9 & 1 \\
\hline 56. & PSC Industries Bhd & 0 & 0 & 0 & 0 & 0 & 0 \\
\hline 57. & United Plantations Bhd & 0 & 86 & 33 & 0 & 31 & 23 \\
\hline 58. & BIMB Holdings Bhd & 0 & 0 & 0 & 0 & 0 & 1 \\
\hline 59. & KFC Holdings (M) Bhd & 0 & 1 & 0 & 0 & 3 & 0 \\
\hline 70. & MTD Capital Bhd & 2 & 1 & 0 & 5 & 2 & 1 \\
\hline 71. & Chemical Company of Malaysia Bhd & 5 & 2 & 17 & 10 & 3 & 11 \\
\hline 72. & Hume Industries (M) Bhd & 1 & 1 & 4 & 2 & 2 & 4 \\
\hline 73. & OSK Holdings Bhd & 0 & 0 & 0 & 0 & 0 & 0 \\
\hline 74. & Naluri Bhd & 1 & 0 & 0 & 4 & 0 & 0 \\
\hline
\end{tabular}


Gadjah Mada International Journal of Business, January -April 2009, Vol. 11, No. 1

\section{Continued from Appendix D}

\begin{tabular}{|c|c|c|c|c|c|c|c|}
\hline \multirow[b]{2}{*}{ No } & \multirow[b]{2}{*}{ Companies } & \multicolumn{3}{|c|}{ Quantity } & \multicolumn{3}{|c|}{ Quality } \\
\hline & & 99 & 03 & 06 & 99 & 03 & 06 \\
\hline 75. & Tan Chong Motor Holdings Bhd & 0 & 0 & 0 & 0 & 0 & 0 \\
\hline 76. & MAA Holdings Bhd & 0 & 0 & 0 & 0 & 0 & 0 \\
\hline 77. & Ta Ann Holdings Bhd & 3 & 17 & 54 & 8 & 18 & 19 \\
\hline 78. & Transmile Group Bhd & 0 & 1 & 10 & 0 & 3 & 9 \\
\hline 79. & Globetronics Technology Bhd & 0 & 0 & 3 & 0 & 0 & 7 \\
\hline 80. & YTL Cement Bhd & 0 & 1 & 4 & 0 & 7 & 4 \\
\hline 81. & MBM Resources Bhd & 0 & 0 & 1 & 0 & 0 & 1 \\
\hline 82. & Selangor Properties Bhd & 0 & 0 & 0 & 0 & 0 & 0 \\
\hline 83. & TIME Engineering Bhd & 3 & 0 & 0 & 4 & 0 & 0 \\
\hline 84. & Tradewinds (M) Bhd & 35 & 30 & 31 & 24 & 28 & 15 \\
\hline 85. & Boustead Holdings Bhd & 3 & 6 & 7 & 6 & 3 & 6 \\
\hline 86. & Berjaya Land Bhd & 1 & 0 & 0 & 3 & 0 & 1 \\
\hline 87. & Utama Banking Group Bhd & 0 & 0 & 0 & 0 & 0 & 0 \\
\hline 88. & Sunway Holdings Incorporated Bhd & 0 & 0 & 6 & 0 & 0 & 11 \\
\hline 89. & Malaysian Mosaics Bhd & 2 & 0 & 0 & 5 & 0 & 0 \\
\hline 90. & W T K Holdings Bhd & 0 & 6 & 12 & 0 & 7 & 14 \\
\hline 91. & Esso Malaysia Bhd & 0 & 3 & 21 & 0 & 10 & 10 \\
\hline 92. & Mulpha International Bhd & 0 & 0 & 1 & 0 & 0 & 3 \\
\hline 93. & Cahya Mata Sarawak Bhd & 0 & 30 & 6 & 0 & 27 & 5 \\
\hline 94. & WCT Engineering Bhd & 0 & 0 & 1 & 0 & 0 & 2 \\
\hline 95. & Malaysian National Reinsurance Bhd & 0 & 0 & 0 & 0 & 0 & 1 \\
\hline \multirow[t]{2}{*}{96.} & Talam Corporation Bhd & 0 & 0 & 0 & 0 & 0 & 0 \\
\hline & Mean & 3.83 & 14.10 & 12.27 & 4.11 & 7.47 & 6.82 \\
\hline
\end{tabular}

